\title{
EFFECT OF ANTISERUM TO OVINE LUTEINIZING HORMONE ON CORPUS LUTEUM FUNCTION
}

\section{IN MICE}

\author{
SAFIA R. MUNSHI, TARALA V. PURANDARE AND SHANTA S. RAO \\ Division of Fundamental Research, Institute for Research in Reproduction (ICMR), \\ Jehangir Merwanji Street, Bombay 12, India
}

(Received 4th May 1971, accepted 10th August 1971)

\begin{abstract}
Summary. The effect of an antiserum to ovine LH was studied on implantation and deciduoma formation in mice. Administration of the LH antiserum on Day 4 of pregnancy and pseudopregnancy inhibited, respectively, the implantation and decidual cell reaction. The administration of progesterone at the same time as the antiserum overcame the inhibitory effects of the antibodies to LH. The results of these studies indicate that the anti-implantation activity of the LH antiserum is manifest by its inhibition of progesterone synthesis by the cL.
\end{abstract}

\section{INTRODUCTION}

In our earlier reports (Munshi \& Rao, 1967; Rao \& Munshi, 1968), antiserum to ovine LH was observed to inhibit oestrus and implantation in the mouse. A specific antiserum to ovine $\mathbf{L H}$ was observed to inhibit implantation in rats (Hayashida \& Young, 1963; Madhawa Raj, Sairam \& Moudgal, 1967, 1968). The present paper gives a detailed account of our work on the mode of action of $\mathrm{LH}$ in the implantation of the mouse blastocyst.

\section{MATERIALS AND METHODS}

Swiss strain female mice used in the study were obtained from the animal colony of the Institute. The females were placed with males of proven fertility overnight and examined for the presence of a vaginal plug the next morning. The day on which a vaginal plug was observed was taken as Day 1 of pregnancy.

Antiserum to ovine LH was prepared in rabbits according to the method of Munshi \& Rao (1965). The sera from the various bleedings were pooled and absorbed with normal sheep serum before being used for biological study.

\section{Experiment 1. Effect of $L H$ antiserum on implantation}

A single dose of $0.2 \mathrm{ml}$ antiserum was injected subcutaneously at 10.00 hours into each of the five animals of the experimental group on any day from Days 1 to 7 of pregnancy. On Day 12, the animals were killed and the ovarian and uterine weights, the number of CL and the nature and number of implantation sites were noted. 
Experiment 2. Effect of steroid supplementation on implantation in mice treated with antiserum

The anti-implantation activity of $\mathrm{LH}$ antiserum was studied by experiments carried out in fourteen groups of mice, each group consisting of five animals, with the exception of Groups 1 (fifteen mice), 8 (nine mice) and 9 (six mice). Experiments with LH antiserum were performed on Day 4 of pregnancy which is a critical phase in the normal pregnancy of rodents. Laparotomy was carried out on Day 12 and the mice were killed on Day 19 of pregnancy unless otherwise indicated. At laparotomy, the nature and number of implantation sites were noted. At autopsy, the ovarian and uterine weights, the number of cL and the nature and number of implantation sites of growing fetuses were noted. The animals in Group I were injected with $0.2 \mathrm{ml}$ of the antiserum to LH only at 10.00 hours on Day 4 of pregnancy. Groups 2, 3 and 4 were given LH antiserum at 10.00 hours on Day 4 of pregnancy and varying doses of oestradiol at 18.00 hours on the same day. The animals in Groups 5 and 6 were given a single dose of $1 \mathrm{mg}$ progesterone at 10.00 hours and 18.00 hours, respectively, the antiserum being administered at 10.00 hours on the same day to both the groups. The antiserum-treated mice in Group 7 were given a single injection of progesterone with oestradiol at 18.00 hours on Day 4 of pregnancy. In Group $8,0.2 \mathrm{ml} \mathrm{LH}$ antiserum was given on Day 4 at 10.00 hours and $1 \mathrm{mg}$ progesterone was given daily from Days 4 to 18 of pregnancy. Group-9 mice received progesterone only up to Day 11 of pregnancy. Groups 10 to 14 received $0.1 \mathrm{ml}$ of $\mathrm{LH}$ antiserum at 10.00 hours on Day 4.

Groups 11,12 and 13 received $0 \cdot 1,0.05$ and $0.025 \mu \mathrm{g}$ oestradiol, respectively, along with the antiserum. One mg of progesterone was administered from Days 4 to 11 to the mice in Group 14 which had received LH antiserum on Day 4.

Experiment 3. Effect of $L H$ and prolactin on implantation in mice treated with antiserum

The effects of a single injection of $1 \mathrm{mg} \mathrm{LH}$ given to one group of four mice treated with $\mathrm{LH}$ antiserum and of $2 \mathrm{mg}$ prolactin given to a second group of four mice also treated with antiserum were compared with those in a group of five control mice which received antiserum alone.

\section{Experiment 4. Effect of LH antiserum on deciduoma formation in pseudopregnant mice}

Pseudopregnancy was induced by mating females with vasectomized males. In order to induce the formation of a deciduoma, the lumen of one uterine horn was scratched with a needle on Day 4 of pseudopregnancy. The control group (Group 1) consisted of six animals and the three experimental groups treated with antiserum consisted of four animals each. Group 2 received $0.1 \mathrm{ml}$ antiserum on Day 4. Group 3 also received $1 \mathrm{mg}$ progesterone from Days 4 to 7 and Group 4 received $2 \mathrm{mg}$ prolactin on Day 4.

\section{RESULTS}

Administration of $\mathrm{LH}$ antiserum on any day from Days 2 to 7 of pregnancy caused a complete inhibition of implantation in all the animals.

Since this inhibition might have been due to interference with the synthesis 
of oestrogen or progesterone by the ovary, the ability of these hormones, singly or in combination, to overcome the inhibitory effect of $\mathbf{L H}$ antiserum was tested. As can be seen from Table 1, antiserum given on Day 4 inhibited implantation.

TABLE 1

EFFECT OF LH ANTISERUM AND STEROIDS ON IMPLANTATION IN THE MOUSE

\begin{tabular}{|c|c|c|c|c|c|}
\hline \multirow{2}{*}{ Group } & \multicolumn{3}{|c|}{ Treatment given on Day 4} & \multicolumn{2}{|c|}{$\begin{array}{c}\text { No. of mice showing implantation } \\
\text { sites/fetuses }\end{array}$} \\
\hline & $\begin{array}{c}\text { Antiserum } \\
10.00 \\
\text { hours }\end{array}$ & $\begin{array}{c}\text { Oestradiol } \\
18.00 \\
\text { hours }\end{array}$ & $\begin{array}{c}\text { Progesterone } \\
10.00 \\
\text { hours }\end{array}$ & Day 10 & Day 19 \\
\hline 1 & $0.2 \mathrm{ml}$ & - & - & $0 / 15$ & - \\
\hline 2 & $0.2 \mathrm{ml}$ & $0 \cdot 1 \mu \mathrm{g}$ & - & $0 / 5$ & - \\
\hline 3 & $0.2 \mathrm{ml}$ & $0.05 \mu \mathrm{g}$ & - & $0 / 5$ & - \\
\hline 4 & $0.2 \mathrm{ml}$ & $0.025 \mu \mathrm{g}$ & - & $0 / 5$ & - \\
\hline 5 & $0.2 \mathrm{ml}$ & - & $1 \mathrm{mg}$ & $0 / 5$ & $0 / 5$ \\
\hline 6 & $0.2 \mathrm{ml}$ & - & $1 \mathrm{mg} *$ & $0 / 5$ & $0 / 5$ \\
\hline 7 & $0.2 \mathrm{ml}$ & $0.025 \mu \mathrm{g}$ & $1 \mathrm{mg*}$ & $0 / 5$ & $0 / 5$ \\
\hline 8 & $0.2 \mathrm{ml}$ & - & $1 \mathrm{mgt}$ & $9 / 9$ & $9 / 9$ \\
\hline 9 & $0.2 \mathrm{ml}$ & 一 & $1 \mathrm{mg}$ & $6 / 6$ & $0 / 6$ \\
\hline 10 & $0.1 \mathrm{ml}$ & - & - & $0 / 5$ & - \\
\hline 11 & $0.1 \mathrm{ml}$ & $0 \cdot 1 \mu \mathrm{g}$ & - & $0 / 5$ & - \\
\hline 12 & $0.1 \mathrm{ml}$ & $0.05 \mu \mathrm{g}$ & - & $0 / 5$ & 一 \\
\hline 13 & $0.1 \mathrm{ml}$ & $0.025 \mu \mathrm{g}$ & - & $0 / 5$ & - \\
\hline 14 & $0.1 \mathrm{ml}$ & - & $1 \mathrm{mgt}$ & $5 / 5$ & $5 / 5$ \\
\hline
\end{tabular}

* Progesterone injected at 18.00 hours on Day 4 only.

$\dagger$ Progesterone injected from Day 4 to Day 18 of pregnancy.

$\$$ Progesterone injected from Day 4 to Day 11 of pregnancy.

TABLE 2

EFFECT OF LH AND PROLACTIN ON IMPLANTATION IN ANTISERUMTREATED MICE

\begin{tabular}{c|cc|c}
\hline \multirow{4}{*}{ Group } & $\begin{array}{c}\text { Treatment on Day } 4 \\
\text { of pregnancy }\end{array}$ & $\begin{array}{c}\text { No. of mice showing } \\
\text { implantation sites on Day 12 }\end{array}$ \\
\cline { 2 - 3 } & Antiserum & Pituitary hormones & $0 / 5$ \\
1 & $0.1 \mathrm{ml}$ & - & $4 / 4$ \\
3 & $0.1 \mathrm{ml}$ & $1 \mathrm{mg}$ ovine LH & $0 / 4$ \\
\hline
\end{tabular}

The results also indicated that oestradiol in the doses used was unable to overcome the inhibitory effect of the antiserum, and that a single dose of progesterone, either alone or in combination with oestradiol, was not effective in maintaining implantation in treated mice. The inhibitory effect of $\mathrm{LH}$ antiserum was overcome, however, by the simultaneous administration of $1 \mathrm{mg}$ progesterone daily from Days 4 to 18 of pregnancy. The implantation sites which were observed on Day 12 were secondarily resorbed in the animals of Group 9 which received progesterone only up to Day 11 of pregnancy. When progesterone $(1 \mathrm{mg} / \mathrm{day}$ ) 
was given with $0.1 \mathrm{ml}$ antiserum from Days 4 to 11 , all the animals in Group 14 were able to carry the pregnancy to term.

Prolactin is generally considered to be a luteotrophic hormone in the rat. The possibility of a similar function in the mouse was therefore investigated (Table 2). A single injection of LH given simultaneously with LH antiserum was capable of maintaining implantation but prolactin was unable to overcome the effect of LH antiserum.

The results (Tables 1 and 2) suggest that, in the mouse, administration of $\mathbf{L H}$ antiserum on Day 4 of pregnancy inhibits the biosynthesis of progesterone by the

TABLE 3

EFFEGT OF LH ANTISERUM ON DEGIDUAL CELL RESPONSE IN MICE

\begin{tabular}{|c|c|c|c|}
\hline $\begin{array}{l}\text { Treatment group } \\
\text { (No. of animals) }\end{array}$ & $\begin{array}{c}\text { Ovaries } \\
\text { (Mean wt } \pm S . D .)\end{array}$ & $\begin{array}{c}\text { Control uterine } \\
\text { horn } \\
\text { (Mean wt } \pm \text { S.D.) }\end{array}$ & $\begin{array}{c}\text { Traumatized } \\
\text { horn } \\
(\text { Mean wt } \pm S . D .)\end{array}$ \\
\hline Trauma $(6)$ & $44 \cdot 03 \pm 2 \cdot 9$ & $243 \cdot 91 \pm 52 \cdot 3$ & $635 \cdot 41 \pm 332 \cdot 4$ \\
\hline $\begin{array}{l}\text { Trauma }+ \text { antiserum } \\
\text { to } \mathrm{LH}(4)\end{array}$ & $34 \cdot 73 \pm 4 \cdot 5$ & $121 \cdot 51 \pm 16 \cdot 6$ & $155.01 \pm 15.4$ \\
\hline $\begin{array}{l}\text { Trauma }+ \text { antiserum } \\
\quad+\text { progesterone }(4)\end{array}$ & $34 \cdot 33 \pm 2 \cdot 8$ & $196 \cdot 87 \pm 25 \cdot 3$ & $547 \cdot 49 \pm 204 \cdot 8$ \\
\hline $\begin{array}{l}\text { Trauma +antiserum } \\
\quad+\text { prolactin }(4)\end{array}$ & $36 \cdot 85 \pm 7 \cdot 3$ & $206 \cdot 27 \pm 83 \cdot 4$ & $285 \cdot 25 \pm 96 \cdot 1$ \\
\hline
\end{tabular}

* Uterine horn traumatized on Day 4 of pseudopregnancy; antiserum, progesterone and prolactin injected on same day.

CL. If this is so, then the antiserum might be expected to interfere with the decidual cell response which can be induced only in a progesterone-stimulated uterus.

As can be observed from Table 3, the injection of the $\mathrm{LH}$ antiserum resulted in a significant inhibition of decidual cell response. While progesterone given from Days 4 to 7 was able to overcome this inhibitory effect, prolactin given as a single dose was ineffective.

\section{DISCUSSION}

The antigenic composition of ovine LH and its cross reactions with various other gonadotrophins have been reported by several workers (Moudgal \& $\mathrm{Li}, 1961$; Segal, Laurence, Perlbachs \& Hakim, 1962; Munshi \& Rao, 1965, 1967; Ely \& Chen, 1966, 1968; Chen \& Ely, 1967).

In the laboratory rat, antibodies to LH have been observed to inhibit implantation (Hayashida \& Young, 1963; Madhawa Raj, Sairam \& Moudgal, 1967, 1968) and pregnancy (Loewit, Badawy \& Laurence, 1969; Loewit \& Laurence, 1969; Madhawa Raj \& Moudgal, 1970). Although the mechanism by which the antibody elicits its inhibitory effect is still not very clear, the above studies have indicated that $\mathrm{LH}$ plays a major rôle in the maintenance of pregnancy in rats.

In the mouse, antibodies to LH have been shown to inhibit the oestrous 
cycle (Ely, 1956, 1960; Ely, Tuerke \& Chen, 1966; Munshi \& Rao, 1967; Rao \& Munshi, 1968) and implantation (Munshi \& Rao, 1967).

The studies reported in this paper have shown that LH plays an equally important rôle in maintaining CL function during implantation in the intact mouse. The effects of LH antiserum administered on Day 4 of pregnancy and the reversal of this effect by progesterone point to an overall control of the synthesis of progesterone rather than of oestrogen as suggested by Madhawa Raj, Sairam \& Moudgal (1968). In a later publication, Madhawa Raj \& Moudgal (1970) reported that a single injection of progesterone could reverse the LH-antiserum-induced inhibition of implantation. This reversal was ascribed by them to the presence of an oestrogenic contaminant in the hormone preparation. The progesterone effect obtained by us cannot be attributed to such a contamination since a similar dose was unable to induce implantation in ovariectomized mice (unpublished data).

$\mathrm{It}$ is well known that the CL formed at ovulation will degenerate within a short time if pregnancy does not follow. In pregnancy, the cL continues to grow and the progesterone output increases gradually up to Day 12 of pregnancy. That LH antiserum blocked the synthesis of progesterone by the CL is confirmed by the results of implantation being inhibited by the antiserum when administered on any day of pregnancy from Day 2 to Day 7 . The antiserum, however, failed to inhibit implantation when administered on Day 1 of pregnancy. It has been shown that the level of progesterone secretion during the first 2 days of pregnancy or pseudopregnancy is relatively low (Psychoyos, 1966). This might be the reason for the inability of the antiserum to be effective in inhibiting implantation when administered on Day 1 of pregnancy.

That progesterone synthesis was inhibited by the administration of LH antiserum to intact mice was further confirmed by the results of the decidual cell response. The pioneering work of Loeb (1908) has shown that a progesterone-dominated uterus is essential for decidualization. Administration of LH antiserum on Day 4 of pseudopregnancy to intact, traumatized mice caused a complete inhibition of deciduoma formation. This effect was reversed by the simultaneous administration of progesterone but not of prolactin.

The results reported in this communication indicate that neutralization of LH activity in the mouse by $\mathrm{LH}$ antiserum results in the formation of a nonfunctional cL leading to the inhibition of implantation. This is in agreement with the data of Loewit et al. (1969) for the rat.

\section{AGKNOWLEDGMENTS}

The LH (NIH-LH-s14) used in this study was a gift of the Endocrine Study Section, National Institutes of Health, Bethesda, U.S.A. Oestradiol-17 $\beta$ and progesterone were gifts from W. Merell Company, U.S.A., and Wyeth Laboratories, India, respectively.

\section{REFERENGES}

CHEN, B. L. \& ELY, C. A. (1967) Immunological studies of the luteinizing hormone. II. Comparative study of antigenic components. Gen. comp. Endocr. 9, 193. 
ELY, C. A. (1956) Effect of antigonadotrophic serum on recent intrasplenic ovarian implants of castrate mice. Endocrinology. 59, 83.

ELy, C. A. (1960) Gonadotropic antiserum effects in normal and irradiated female mice. Proc. Soc. exp. Biol. Med. 105, 111.

Ely, C. A. \& Chen, B. L. (1966) Immunological studies of the luteinizing hormone. I. Identification of the antigenic components of sheep luteinizing hormone and the development of a serologically specific antiserum. Endocrinology, 79, 362.

ELY, C. A. \& CHEN, B. L. (1968) Immunological studies of the luteinizing hormone. IV. Characterization of the cross-reactions with pregnant mare's serum gonadotropin. Endocrinology, 83, 414.

Ely, C. A., Tuerke, R. \& Chen, B. L. (1966) Comparison of antisera to various gonadotropins as they effect the mouse vaginal cycle. Proc. Soc. exp. Biol. Med. 122, 601.

HAYAShIDA, T. \& YounG, W. P. (1963) Interruption of pregnancy in rats with antiserum. Anat. Rec. 145, 323.

LOEB, L. (1908) The production of deciduomata and the relation between the ovaries and the formation of the decidua. F. Am. med. Ass. 50, 1897.

Loewit, K., Badawy, S. \& LAURence, K. (1969) Alteration of corpus luteum function in the pregnant rat by antiluteinizing serum. Endocrinology, 84, 244.

LOEWit, K. \& LAURENCE, K. (1969) Termination of pregnancy in the rat with rabbit antibovine LH serum. Fert. Steril. 20, 679.

Madhawa RaJ, H. G. \& Moudgal, N. R. (1970) Hormonal control of gestation in the intact rat. Endocrinology, 86, 874.

Madhawa RaJ, H.-G., Satram, M. R. \& Moudgal, N. R. (1967) Role of gonadotropins in implantation: a study using specific antigonadotropins. Indian f. exp. Biol. 5, 123.

Madhawa RaJ, H. G., Sairam, M. R. \& Moudgal, N. R. (1968) Involvement of luteinizing hormone in the implantation process of the rat. F. Reprod. Fert. 17, 335.

Moudgal, N. R. \& LI, G. H. (1961) An immunochemical study of sheep pituitary interstitial cell stimulating hormone. Archs Biochem. Biophys. 95, 93.

Munshi, S. R. \& RAO, S. S. (1965) An immunological study of sheep pituitary luteinizing hormone. Indian F. exp. Biol. 3, 136.

Munshi, S. R. \& RAo, S. S. (1967) Biological specificity of antigens present in ovine luteinizing hormone. Indian. F. exp. Biol. 5, 135.

Psychoyos, A. (1966) Recent research on egg implantation. In: Egg Implantation. Ciba Foundation Study Group No. 23. Eds. G. E. W. Wolstenholme and M. O'Connor. Ghurchill, London.

Rao, S. S. \& Munshi, S. R. (1968) Immunological investigations with gonadotropin hormones. Bull. natn. Inst. Sci. India, 36, 96.

Segal, S. J., Laurence, K. A., Perlbachs, M. \& Hakim, S. (1962) Immunologic analysis of sheep pituitary gonadotropins. Gen. comp. Endocr. Suppl. 1, 12. 